\title{
The Chief Justice, Racial Segregation, and The Friendly Critics
}

\author{
Ira Michael Heyman*
}

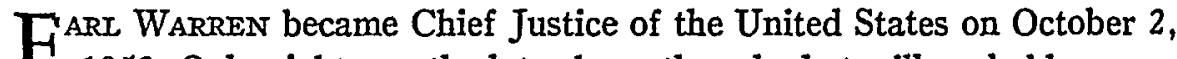
L 1953. Only eight months later he authored what will probably prove to be the most momentous judicial decision of the century-Brown v. Board of Education. ${ }^{1}$ The Chief Justice wrote for a unanimous Court. Conceivably, we will some day know how unanimity was reached. What was the role of the Chief Justice's predecessor ${ }^{2}$ Was it necessary to woo and win those members of the Court with Southern backgrounds? ${ }^{3}$ How were the lines drawn in December of 1953, when the cases were argued for a second time? Are the speculations correct which credit the newly arrived Chief Justice with the unanimous statement? Was the opinion in the cases shaped by adamant refusals to concur unless this or that approach was utilized?

Whether or not the Chief Justice was responsible for the unanimity of devision and the statement of opinion, his choice to be the Court's spokesman will forever identify Earl Warren as much with desegregation as is John Marshall with judicial review. As Chief Justice, Earl Warren was the "first among equals" in deciding the case; as the writer of the opinion, he was the identifiable spokesman of the Court.

The Brown decision has drawn heavy fire from persons to whom the Court's action is an anathema. One hardly could have expected otherwise. These spirited attacks have drawn counterfire. The charges and answers are too well known to bear repetition here. Recently, however, criticism has been leveled by two renowned scholars who abhore segregation. One is Professor Herbert Wechsler, who agrees that segregation should be stamped

* Acting Associate Professor of Law, University of California School of Law, Berkeley.

1347 U.S. 483 (1954). Brown v. Board of Education was one of four cases involving state enforced public school segregation. The other three were consolidated with Brown for argument and opinion. They were Briggs v. Elliot (from South Carolina); Davis v. County School Board of Prince Edvard County, Virginia (from Virginia); and Gebhart v. Belton (from Delaware). Also decided on the same day was Bolling v. Sharpe, 347 U.S. 497 (1954), whicl came from the District of Columbia.

2 Chief Justice Vinson died just prior to the comenencement of the October 1953 Tern of the Court. He had presided when the cases were first argued on December 7-11, 1952.

$3 \mathrm{Mr}$. Justice Hugo L. Black (Alabama), Mr. Justice Stanley Reed (Kentucky), Mr. Justice Tom C. Clark (Texas). 
out but can find no legal basis for a Court decision doing so. ${ }^{4}$ The other is Professor Louis Pollak, who agrees with the Court's action but believes that the opinion of the Chief Justice was intellectually insufficient and that another rationale would have been preferable. ${ }^{5}$

Professor Pollak's criticism assumes that the Court's decision was based on the ground that segregation "harms" Negroes by inaking them feel inferior. Both commentators are dissatisfied with that ground. Professor Wechsler indicates that there was no factual basis in the record for such a finding and that, in any event, "harm". is immaterial. Professor Pollak indicates that the Court is unable wisely to make such a determination. Professor Pollak, and to some extent Professor Wechsler, interpret the opinion as making "harm" the sine qua non of unconstitutionality: If no "harm" results from segregation, it is presumably constitutional. Both commentators are, by necessity, critical of the Chief Justice's opinion.

Since the publication of the Pollak and Wechsler views, Professor Charles Black has written a rejoinder in which he appears to agree that the Court's determination was based on a finding that Negroes are "harmed" by segregation. ${ }^{\circ}$ Unlike Wechsler and Pollak, however, Black argues that such a basis for the decision was correct. And he does not appear to reject the notion that a finding of "harm" is a necessary basis for holding segregation unconstitutional.

I believe that Professors Wechsler, Pollak and Black have misread the Brown opmion and that in large part the Wechsler and Pollak criticisnis are unjustified. In my view, the opinion, read properly, establishes the proposition that the fourteenth amendnent renders invalid laws employing racial classifications in the field of public education wliether or not Negroes are nrade to feel inferior thereby. I believe that "harm" was relevant under the circumstances only to illustrate that such a construction of the amendment was especially justified and that the opinion did not imply that absent a finding of "harm" racial segregation would be constitutional. Alternatively, if the Pollak-Black reading is correct, I believe that the Chief Justice was speaking about "harm" in the sense of intentionally induced feelings of inferiority, and I agree with Professor Black that the Court, for reasons to be discussed, could properly rely upon its existence as a basis of decision.

This article will re-examine the Brown opinion in detail and describe, analyze and, hopefully, rebut the criticisms of Professors Wechsler and Pollak.

4 Wechsler, Toward Neutral Principles of Constitutional Law, 73 HARv. L. Rev. 1 (1959) (hereinafter cited as "Wechsler"). Professor Wechsler's article was first delivered as the Oliver Wendell Holmes Lecture at Harvard Law School on April 7, 1959.

5 Pollak, Racial Discrimination and Judicial Integrity: A Reply to Profcssor Wechsler, 108 U. PA. L. REv. 1 (1959) (hereinafter cited as "Pollak"). See also Pollak, The Supreme Coutr Under Fire, 6 J. PUB. L. 428 (1957).

- Black, The Lawfulness of the Segregation Decisions, 69 YarE L.J. 421 (1959). 
The Brown decision involved cases from four different states. ${ }^{7}$ In each case but one, the Negro plaintiffs were denied relief on a finding that the separate educational facilities provided for them were "equal" (or would soon be made "equal") to those provided for white children. The "equality" discussed in the lower courts was equality with respect to buildings, curricula, quahifications and salaries of teachers-so-called "tangible factors." The Court thus was faced with the question whether the provision of separate but physically equal schools to nonwhite children was a denial to them of the "equal protection of the laws"-a protection guaranteed by the fourteenth amendment.

The Chief Justice's opinion first turned to the history of the amendment for an answer. Reargument along the lines called for by the Court had produced a series of volumes by the parties (and by the United States as amicus curiae) directed at the question whether the framers and ratifiers of the amendment intended to outlaw segregated education. The Chief Justice concluded that the historical materials were inconclusive on the question in view of the differing intentions of the proponents and opponents of the amendment, the lack of source material indicating how others in Congress and in the ratifying state legislatures interpreted the words of the amendment, and especially in view of the rudimentary stage of public education in the United States in 1868, which probably foreclosed consideration of the effect of the amendment on public education in the minds of many persons concerned in the proposing and ratification procedures. ${ }^{0}$

The opinion next turned to the cases. The Chief Justice stressed that immediately following the adoption of the amendment the Supreme Court had interpreted it as proscribing "all state-imposed discriminations against the Negro race" and as providing an exemption for Negroes

from unfriendly legislation against them distinctively as colored,--exemptions from legal discriminations, implying inferiority in civil society, lessening the security of their enjoyment of the rights which others enjoy, and discriminations which are steps towards reducing them to the condition of a subject race. ${ }^{10}$

${ }^{7}$ See note 1 supra. I do not discuss in this article the opinion of the Chief Justice in Bolling v. Sharpe, 347 U.S. 497 (1954). The statements of Professors Wechsler and Pollak are addressed to the Brozen opinion. They appear to assume, as do I, that if the equal protection clause of the fourteenth amendment properly can be construed to prohibit the states from practicing racial segregation, the due process clause of the fifth amendment would require no less from the federal government.

8 Brown v. Board of Education, 347 U.S. 483, 492 (1954).

9 Id. at 489-90.

10 Id. at 490-91 n.5. The quotation is from Slaughter-House Cases, 83 U.S. (16 Wall.) 36, 67-72 (1873) and Strauder v. West Virginia, 100 U.S. 303, 307-08 (1880). 
The opinion then showed that not until 1896-twenty-eight years after the adoption of the amendment-did the Court accept the "separate but equal" formulation as satisfying its initial, broadly protective interpretation; it further demonstrated that in six cases decided by the Court prior to Broven, which cases involved the application of the doctrine to public educational facilities, only the application and not the doctrine itself was challenged.11

The Chief Justice stated that the question presented could not be decided in the light of 1868 or 1896 , but only in the light of 1954 , by which time public education had matured from a minor governmental service to one of the most important functions of state and local governments. ${ }^{12} \mathrm{Im}$ plicit in this statement, and in that portion of the opinion dealing with the historical materials, was the view that the broadly inclusive words of the equal protection clause were designed to permit a maturing, progressively expanding interpretation as underlying circumstances changed. The stress of the opinion on the greatly increased importance of public education indicated that the changing circumstances deemed relevant by the Chief Justice included not only maturing ethical attitudes but also changes in institutional practices. Thus, while segregation in public education institutions at a time when there were few such facilities and when only a relative handful of Negro children were culturally prepared to follow a curriculum night not have been easily viewed as a denial of equal protection, though such a denial may have existed in fact, continued segregation when public education had become a key governmental service manifestly called for a different evaluation.

The different evaluation, under contemporary circunistances, led to the historic determination that segregation in physically equal schools deprives Negroes of the equal protection of the laws.

The Chief Justice reasoned as follows. ${ }^{13}$ In Sweatt v. Painter, ${ }^{14}$ the Court had relied on the many "qualities which are incapable of objective measurement but which make for greatness in a law school" and had found that a separate law school for Negroes could not provide equal educational opportunities. In McLaurin v. Oklahoma State Regents, ${ }^{15}$ the Court had required that a Negro admitted to a theretofore all-white graduate school be treated like all other students. It had stressed that numerous "intangible considerations" ("ability to study, to engage in discussions and exchange views with other students, and in general to learn his profession") are important in determining whether educational opportunities afforded Negroes are equal to those afforded whites. The considerations applicable to the

11 Brown v. Board of Education, 347 U.S. 483, 491-92 (1954).

12 Id. at 492-93.

$13 \mathrm{Id}$. at $493-95$.

14339 U.S. 629 (1950).

15339 U.S. 637 (1950). 
graduate school cases apply "with added force to children in . . grade schools."16 Racial segregation "harms" Negro children by generating feelings of inferiority as to their status, which detrimentally affects their motivations to learn. This factual determination of "hann" flowing from racial segregation is well exemplified in the opinion of one of the lower court cases under review. ${ }^{17}$ Any language in Plessy v. Ferguson ${ }^{18}$ contrary to this determination is rejected. Regardless of the state of psychological knowledge at the time of the Plessy decision, modern authorities support this determination.

\section{III}

A.

It is quite obvious that the Court determined as a fact that segregation detrimentally affects Negro school children. But is this what rendered segregation in grade schools unconstitutional? The opinion is certainly open to that construction. But it is also open to an alternative construction which relegates the determination of "harm" to support for the conclusion that segregation in grade and secondary schools is a greater denial of equal protection than is segregation in graduate schools-that the considerations applicable in the graduate school cases apply with added force in primary and secondary school cases because, in addition to those considerations, Negro children are demonstrably "harmed" by such segregation in still a different and more significant way than are Negro students who are denied admission to graduate school solely on the basis of race.

The alternative construction proceeds from the Chief Justice's reliance on the Sweatt and McLaurin cases and his somewhat ambiguous reference to the "considerations" applicable in them. Sweatt is cited for the proposition that the inerit of a law school depends not only on physical plant, size of library, number of staff and the like, but also on "qualities which are incapable of objective measurement."19 McLaurin is cited for the proposition that "intangible considerations" are important in determining whether separate educational institutions are equal..$^{20}$ Put these propositions in reverse order and what the Chief Justice is saying is (1) in determining whether separate educational institutions are equal a court must assess not only physical qualities but also intangible ones; (2) "qualities incapable of objective measurement" might be the determining factor in judging the

16347 U.S. 483,494 (1954).

17 The Chief Justice's statement had reference to Gebhart v. Belton, 87 A.2d 862 (Del. 1952).

18163 U.S. 537 (1896).

19347 U.S. 483,493 (1954).

20 Ibid. 
relative merits of different law schools. Add to these propositions the implicit assumption of the opinion that under the fourteenth amendment a Negro cannot be demied anything less than absolute equality of educational opportunity and the result is that a Negro cannot be denied on the basis of race the opportunity to attend any graduate educational program offered in any state school, because the comparative merit of different graduate schools offering similar programs depends in the last analysis on qualities incapable of measurement. In other words, the fourteenth amendment automatically prohibits racially segregated public graduate education, and a court need not inquire into the relative merits of the graduate programs provided for the different races.

This construction miglit be unduly strained if the approach suggested appeared in the Brown opinion for the first time. But in fact a similar approach had previously been utilized in Shelley v. Kraemer. ${ }^{21}$ In that case the Court first found that judicial enforcement of restrictive covenants barring non-Caucasians from occupying residential properties amounted to "state action" within the meaning of the fourteenth amendment. It then held that the action denied the affected Negro parties the equal protection of the laws and that it was no answer that the state stood ready to enforce similar covenants barring occupancy by Caucasians. The Court reasoned that the rights created by the fourteenth amendment are personal, not group rights, and that "equal protection of the laws is not aclieved through indiscriminate imposition of inequalities."22 The Court clearly assumed that the fourteenth amendment prohibits a state from disadvantaging a person because of color or race. And the Court appears to have found the prohibited disadvantaging in that by judicial action a Negro was unable to acquire or possess a specific parcel of real property solely because he was a Negro.

In Shelley, unlike the graduate school cases, the Court did not discuss whether alternative parcels of realty available to the Negro parties were equal to those restricted to white residency. The probable reason for this was that individual parcels of real property historically have been treated as umique, ${ }^{23}$ so that prohibiting a person from acquiring a specific parcel because of his race was easily assumed to be the imposition of a disadvantage or inequality on the basis of race. In the school cases, however, the state had attempted to provide equal schools. This required the Court to spell out why it was impossible to measure the relative worth of different schools simply by considering tangible qualities. But once the Court reached the conclusion that different schools were umique, then the Shelley reasoning was applicable.

21334 U.S. 1 (1947).

22 Id. at 22.

23 See 5 Corbin, Contracts $\$ 1143$ (1951); 5 Wuluston, Contracts $\$ 1419$ (1937). 


\section{B.}

Professor Pollak, as well as others, has interpreted the Brown opinion as standing for the proposition that racial segregation in education denies Negroes the equal protection of the laws solely because it "harms" them by generating in them feelings of inferiority. ${ }^{24}$ Professor Wechsler has recognized that this is a possible construction. ${ }^{25}$ This view leads to difficult problems such as whether a legislature can balance "harms" of this nature against other "harms" arguably visited on whites by desegregation and conclude, consistent with the Constitution, that segregation causes the fewest "harms," or that Negro children would be nore "harmed" by desegregation than by continued segregation. Perhaps the mere presence of such difficulties supports the adoption of the alternative construction here urged. In any event, it seems strange that the commentators who find that "harm" was the determinant fail to discuss the Chief Justice's reliance on Sweatt and McLaurin and his comment that the considerations upon which those decisions were based apply with "added force" to primary and secondary school segregation.

\section{C.}

Professor Wechsler refuses to believe that the Court rejected the "separate but equal" doctrine on sufficient record evidence or judicially noticed facts to sustain a finding that segregation "harms" Negro children. ${ }^{26}$ This follows, apparently, from the paucity of evidence (convincing to Professor Wechsler) supporting this conclusion, for he questions the reliability of the evidence given by experts in the lower courts and asks whether it would not be relevant that, under the specific circumstances involved in some of the cases, separation rather than integration would arguably maximize relevant goals of the Negro children.

He states that the decision "nuust have rested on the view that racial segregation is, in principle, a denial of equality to the minority against whom it is directed; that is, the group that is not dominant politically and, therefore, does not make the choice involved." 27 This rationale is unsatisfactory to Professor Wechsler, however, for he sees it as an inquiry into the "motive" of the legislature, which in his view should be foreclosed to a court, or, alternatively, as a decision based on the way those affected by legislation view it. He sees no validity in the latter proposition and suggests that Plessy was correct in stating that "if 'enforced separation stamps the

24 This is the necessary implication of Professor Pollak's alternative opinion for the Brown case. See Pollak 28.

25 Wechsler 32-33.

$26 I d$. at 33 .

27 Ibid. 
colored race with a badge of inferiority' it is solely because its members choose 'to put that constructition upon it." "28

He concludes that the question posed by enforced segregation is not one of discrimination, but one of denial to Negroes (and others) of freedom to associate, which must be balanced with the forced association (repugnant to Southern whites) implicit to him in constitutionally required desegregation. Faced with these two demands, Professor Wechsler is unable to find a neutral principle to determine the case; le confesses that he has not yet found a way to write the opinion. Professor Wechsler thus seemingly suggests that the Court's role was withdrawal. ${ }^{29}$

As I suggest above, I do not believe that the Chief Justice's opinion was based on the principle suggested by Professor Wechsler. Rather, the opinion is best interpreted as stating that racial segregation in state-provided educational institutions results in denials of equal protection of the laws because it prohibits persons, on the basis of race, from gaining admission to inherently unique facilities. Of course, in this context, as pointed out by Professor Wechsler, the opinion does not hold that the fourteenth amendment prohibits all legislation which uses racial classifications and it fails to overrule Plessy v. Ferguson except insofar as that case was applied to educational facilities. In ny view sucl sweeping rulings were properly avoided. ${ }^{30}$

IV

If, however, Professor Wechsler is correct in rejectimg nry interpretation, I still think that the decision was sound. Professor Wechsler believes

28163 U.S. 537, 551 (1896).

29 Wechsler 34.

30 Professor Wechsler seems to suggest that the Court would have been on firmer ground had it explicitly overruled Plessy v. Ferguson and read the fourteenth amendment as prohibiting all racial classifications. He intimates that the Court later took this position in the course of its per curian decisions in segregation cases. Apparently, however, Professor Wechsler rejects the validity of this alternative in view of his confession of inability to fashion any convincing basis for the decision.

If one interprets the opinion as I suggest, as resting on the uniqueness of different schools, it was of course unnecessary for the Court to embrace the more sweeping position. But even if the basis for decision was something else, it certainly can be argued with reason that the Court wisely rejected, in 1954, adopting a rule which would make invalid in every conceivable situation any statute incorporating racial distinctions. Constitutional law-Inaking, as common-law law-making, should in large part be experiential. This is the genius of the Anglo-American legal system. A Court should be hesitant to fashion broad binding rules, especially when interpreting a document like the Constitution, not absolutely necessary to determine the case before it. It is one thing to talk about broad principles of generahty in the abstract; it is another to create and apply a sweeping principle in the area of race relations which determines not ouly the case before the Court, but other, more difficult cases also. Should the Court, without argument, have determined, in 1954, that legislation designed to aid Negroes to become accepted as first-class citizens, perhaps legislation creating special scholarships for Negroes, would be invalid? Presumably a "color blind" Constitution would require such a result. The Court wisely did not go this far. Perhaps after a series of cases holding invalid one and then another statute which makes racial distinctions, the suggested sweeping rule ought to be announced. But 1954 was too early for that. 
that the decision rested on the view that racial segregation is, in principle, a denial of equality to Negroes, the group against which it is directed. His criticism is that such a basis of decision requires an inquiry into legislative "motive" or, alternatively, is grounded in the way in which Negroes interpret racial segregation.

The point to be niade at the outset is that Professor Wechsler's whole argument depends on his refusal to consider that the Court might have based its decision on a determination that Negroes are intentionally niade to feel inferior through the nrechanism of segregation. Wechsler reads "harm" out of the case for purposes of his argument. He also presumes that the court dealt with equal schools. Once all references to "harnis," disadvantages, or inequalities are excised, it admittedly beconies difficult to find any valid equal protection basis for the decision. But for the reasons to be stated, I beheve that the Court properly could take into account the "harms" purposely visited on Negroes by racial segregation. ${ }^{31}$

\section{A. A State is Prohibited by the Equal Protection Clause from Taking Actions Designed to Impose Disadvantages on Negroes on the Basis of Race}

Recent hterature has shown the difficulty of determining with precision the intent of the framers and ratifiers of the fourteenth aniendment. ${ }^{32}$ But regardless of the original intent, the Supreme Court, soon after the amendment's adoption, firmly established that the equal protection clause broadly protects Negroes from discriminatory state action of every kind. Most indicative of the Court's attitude are the following excerpts from its opinions. From the Slaughter-Houses Cases:

$[N] 0$ one can fail to be impressed with the one pervading purpose found in them all [the thirteenth, fourteenth and fifteenth amendments], lying at the foundation of each, and without which none of them would have been even suggested; we mean the freedom of the slave race, the security and firm establishment of that freedom, and the protection of the newly-made freeman and citizen from the oppressions of those who had formally exercised unlimited dominion over him. ${ }^{33}$

In the light of the history of these amendments, and the pervading purpose of them, which we have already discussed, it is not difficult to give a meaning to this [the equal protection] clause. The existence of laws in the

31 The arguments which follow rely heavily on those made by Professor Black. Black, The Lawfulness of the Segregation Decisions, 69 YALE L.J. 421 (1959) (hereinafter cited as "Black").

82 See Bickel, The Original Understanding and the Segregation Decision, 69 HARv. L. REv. 1 (1955); Jasies, The Framung of the Fourteenth Amendmant (1956); tenBroek, The

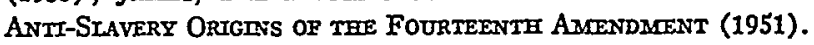

8383 U.S. (16 Wall.) 36, 71 (1873). 
States where the newly emancipated negroes resided, which discriminated with gross injustice and hardship against them as a class, was the evil to be remedied by this clause, and by it such laws are forbidden. ${ }^{34}$

\section{From Ex Parte Virginia:}

One great purpose of these amendments was to raise the colored race from that condition of inferiority and servitude in which most of them had previously stood, into perfect equality of civil rights with all other persons within the jurisdiction of the States. They were imtended to take away all possibility of oppression by law because of race or color. ${ }^{35}$

\section{Finally, from Strauder v. West Virginia:}

What is this [the text of section 1 of the fourteeenth amendment] but declaring that the law in the States shall be the same for the black as for the white; that all persons, whether colored or white, shall stand equal before the laws of the States, and, in regard to the colored race, for whose protection the amendment was primarily designed, that no discrimination shall be made against them by law because of their color? The words of the amendment, it is true, are prohibitory, but they contain a necessary implcation of a positive immunity, or right, nost valuable to the colored race,the right to exemption from unfriendly legislation against then distinctively as colored,-exemption from legal discrimmations, implying inferiority in civil society, lessening the security of their enjoyment of the rights which others enjoy, and discriminations which are steps towards reducing then to the condition of a subject race. ${ }^{36}$

\section{B. Racial Segregation "Harms" or Disadvantages Negroes by Making Them Feel Inferior. One of the Demonstrable Purposes of Racial Segregation (Perhaps its Chief One) is to Make Negroes Feel Inferior}

As Professor Black sees it, history shows clearly that segregation "came down in apostolic succession from slavery,"37 was "an integral part of the movement to maintain and further 'white supremacy," "38 "was imposed on one race by the other race ... and is kept going only because the white race has wanted it that way,"39 "is historically and contemporaneously associated in a functioning complex with practices which are indisputedly and

\section{Id. at 81 .}

35100 U.S. 339, 344-45 (1879).

36100 U.S. 303, 307-08 (1879). The Supreme Court, of course, severely limited the effect of the fourteenth amendment by narrowly construing the bounds of official action covered by the amendment. See Gressman, The Unhappy History of Civil Rights Legislation, 50 MrCH. I. REv. 1323 (1952); HARRIS, THE QUEST FOR EQUAIITY (1960). But with the exception of Plessy v. Ferguson it read the amendment as interdicting all kinds of racial discrimination to which, in its view, a state or local government was a party.

37 Black 424.

38 Id. at $424-25$.

39 Id. at 425 . 
grossly discriminatory," function as a means of keeping the Negro in a status of inferiority." "11 Again, in Black's words:

The society that has just lost the Negro as a slave, that has just lost out in an attempt to put him under quasi-servile "Codes," the society that views his blood as a contamination and his name as an insult, that society that extralegally imposes on him every humiliating mark of low caste and that until yesterday kept him in line by lynching-this society, careless of his consent, moved by law, first to exclude him from voting, and secondly to cut him off from mixing in the general public life of the community. The Court that refused to see inequality in this cutting off would be making the only kind of law that can be warranted outrageous in advance-law based on self-imduced blindness, on flagrant contradiction of known fact. ${ }^{42}$

Professor Wechsler's chief difficulties here are that the record did not show persuasively that Negro children are "harmed" by segregation or that Negro children would be less "harmed" by desegregation than by segregation. ${ }^{43}$ As for the first, Professor Black's statements give answer. As for the second, the answer lies in the sources of the respective "harms." For constitutional purposes there is a great difference between "harm" which flows from legislation and "harm" which results from private biases unaided by legal controls. The fourteenth amendment enjoins states, not persons, froin depriving others of equality. The "harm" which flows from enforced segregation is "harm" created, supported and perpetuated by the tools of government in the hands of the white majority. The "harm" which might flow from desegregation is "harm" not fostered by the state but "harm" flowing from private attitudes unaided by the force of government. ${ }^{44}$ Moreover, the Court could reasonably have believed that the "harms" visited on Negroes by segregation would never be effaced under a continued scheme of segregation, while the "harms" which might flow from desegregation most probably would be relatively short lived, especially if desegregation were permitted to proceed slowly and, in any event, had a chance of evaporating over time.

The argument is also made that if "harm" is the constitutional criterion, then it would be proper to take into consideration the "harms" from desegregation which flow to whites. I cannot help but believe that in the last analysis the only "harm" here relevant is the association with Negroes which will be visited on whites by desegregation. I find Professor Black's statement persuasive that freedom of non-association in public facilities is

\section{Ibid.}

41 Ibid.

42 Id. at 426.

43 Wechsler 32-33.

44 Cf. McLaurin v. Oklahoma State Regents, 339 U.S. 637, 641-42 (1950). 
not protected and hence is irrelevant. ${ }^{45}$ But even if other "harms," presumably short-lived, such as disruption of public school education by the hostile reaction of some whites to desegregation, should be taken into consideration, the Court's decision represents to me a proper balancing between competing "harms." I base this primarily on the conclusion that the "harms" flowing to Negroes will continue to flow so long as enforced segregation persists, while the "harms" flowing to whites from desegregation most probably will abate in significance with the passage of time.

\section{The Purpose of Segregation Statutes, to Create and Maintain an Inferior Status for Negroes Has Nothing to do With Leg- islative "Motive" and is Susceptible to Judicial Inquiry}

It was established above that the fourteenth amendment prohibits a state from disadvantaging Negroes on the basis of race. ${ }^{46}$ Normally, when faced with a statute which classifies on the basis of race, as do segregation statutes, a court only inquires whether the parties are disadvantaged in order to determine the statute's validity. There is no inquiry into the aim or purpose of the statute. (For instance, a state law prohibiting Negroes from voting in an election is invalid whether or not the state aimed to harm Negroes by the statute. ${ }^{47}$ For purposes of Professor Wechsler's argnment, it must be presumed that the state is providing "equal" facilities. ${ }^{48}$ The argument following this presumption is that the "harm" which results to Negroes, the generation of feelings of inferiority, is the product solely of the interpretation which Negroes give segregation statutes. ${ }^{49}$ Presumably such "harm" flowing solely from a subjective interpretation of this nature is insufficient to render segregation statutes unconstitutional. But if the state passes segregation statutes for the very purpose of causing such "harm" to occur, then there would seem to be no question but that the statutes are invalid. It was stated above that segregation statutes are aimed at keeping Negroes in an inferior status. Can a court inquire of such an aim?

It is common to state that a court is foreclosed from inquiring into the motives of a legislature. ${ }^{50}$ Here, however, we are not concerned with motivations, but with a purpose or aim of segregation legislation which is not patently disclosed by the statutes themselves.

"Motive" is defined in dictionary terms as "that within the individual, rather than without, which incites him to action; any idea, need, emotion,

45 Black 428-29.

46 See text at notes 30-34 supra.

47 E.g., Nixon v. Herndon, 273 U.S. 536 (1927); Nixon v. Condon, 286 U.S. 73 (1932);

Smith v. Allwright, 321 U.S. 649 (1944); Terry v. Adams, 345 U.S. 461 (1953).

48 Wechsler 33.

$49 \mathrm{Ibid}$.

50 Ibid. 
or organic state that prompts an action." ${ }^{.51}$ The actions with which we deal here are the passage of statutes by white legislatures requiring separation of whites and Negroes in different public schools. One "effect" of these actions is that Negro children are made to feel inferior, made to feel like second-class citizens. On the most elementary level, the "purpose" of the actions is to assure racial separation. On a somewhat more sophisticated level, the "purpose," as Professor Black shows, is to isolate Negroes in order to preserve for whites superior status while simultaneously maintaining for Negroes a position of inferior status-to "keep the Negro in his place." The "motives" inducing individual legislators to take such actions for such purposes are no doubt varied and impossible to discover-in some cases by the legislators themselves; such notives could range from political expediency to irrational sexual fears. One legislator might vote for segregation because he fears that his daughter might otherwise be a partner to a miscegenetic marriage. Another's vote might be stimulated by a desire to keep jobs for white men. A third might honestly believe that Negroes are inferior. But such motivations are irrelevant. We are concerned, rather, with a purpose or aim which does not appear on the face of the statute.

The Court, especially in recent years, has stated often that in constitutional cases the purpose of legislation is none of its affair-that it is concerned merely with power. Perhaps the outstanding statement of this position is contained in United States v. Darby, ${ }^{53}$ where Justice Stone said:

The motive and purpose of a regulation of interstate commerce are matters for the legislative judgment upon the exercise of which the Constitution places no restriction and over which the courts are given no control. ... "The judicial cannot prescribe to the legislative departments of the government limitations upon the exercise of its acknowledged power." Veazie Bank v. Fenno, 8 Wall. 533. Whatever their motive and purpose, regulations of commerce which do not infringe some constitutional prohibition are within the plenary power conferred on Congress by the Commerce Clause. ${ }^{.4}$

The relevant question in issue in Darby was whether Congress could prohibit the interstate shipment of goods produced under labor conditions defined in the statute as substandard. The Court concluded that the power granted Congress by the commerce clause "to regulate Commerce ... among the several States ...." included the power to prohibit such commerce. Once this conclusion was reached the Court deemed it improper to inquire whether this power was being used in order to regulate activities previously held to be only within the competence of the states.

Similar injunctions against inquiring into purpose are implicit in cases

51 Webster, New International Dictronary (2d ed. 1960).

52 Black 424-27.

53312 U.S. 100 (1941).

54 Id. at 115. 
dealing with the validity of federal taxes which seem more to regulate conduct than to raise revenue. Thus, the majority in United States v. Kahriger ${ }^{55}$ sustained a statute which imposed a federal occupation tax on gamblers and required them to make detailed registrations even over Justice Frankfurter's sharp dissent, in which he stated:

Congress may make an oblique use of the taxing power in relation to activities with which Congress may deal directly, as for instance, commerce between the States. . . . However, when oblique use is made of the taxing power as to matters which substantively are not within the powers delegated to Congress, the Court cannot shut its eyes to what is obviously, because designedly, an attempt to control conduct which the Constitution left to the responsibihity of the States, merely because Congress wrapped the legislation in the verbal cellophane of a revenue measure..$^{56}$

The majority, however, followed the lead well-stated in Justice Stone's dissent in United States v. Butler ${ }^{57}$ and found the statute valid because it was an exercise of an admitted taxing power.

Similar judicial reluctance to inquire into legislative purpose is illustrated by the Court's handling of contemporary cases where attacks are leveled on economic regulations as violative of the due process and equal protection guarantees. In the due process cases, especially, the Court has refused to determine "why" the legislature passed the statute and "whether" the statute is addressed to evils which do in fact exist; rather, the Court has presumed the existence of facts supporting the legislative judgment. ${ }^{58}$ Similarly, but not always, in equal protection cases the Court has presumed the existence of facts which render the classifications created by the statute reasonable. ${ }^{59}$

The thesis here propounded is that these cases have only tangential relevance where the charge is made that a statute is invalid under the equal protection clause because a racial group is disadvantaged by it. Support for this thesis is found primarily in the differing meanings of the constitutional provisions involved.

First, the commerce clause and tax cases. Here the Court has interpreted the Constitution as permitting the federal legislature to effectuate any policies which it desires so long as the legislature limits its means to those tools specified in the Constitution. Nothing in the Constitution prohibits this result. The commerce clause is easily read to grant unlimited

65345 U.S. 22 (1953).

60 Id. at 37-38 (dissenting opinion).

57297 U.S. 1, 78 (1936).

58 E.g., United States v. Carolene Products Co., 304 U.S. 144 (1938) ; Olsen v. Nebraska, 313 U.S. 236 (1941).

59 Compare Williamson v. Lee Optical Co. of Oklahoma, 348 U.S. 483 (1955), with Morey v. Doud, 354 U.S. 457 (1957). 
power to Congress to regulate activities which fall within the defined areas of interstate and foreigu commerce. The taxing clause is phrased with similar broadness. Only the redundant tenth amendment counsels otherwise, but it has been viewed as stating a truism..$^{00}$ And the Court's approach accords with a judicial self-conception of limited powers to interfere with legislative determinations-a conception which fits nicely with the attitudes of those who viewed with disfavor the Court's pre-1937 approach to national economic regulation. ${ }^{61}$

Next are the due process and equal protection cases. In the due process cases the Court is saying in substance that the Constitution permits the federal and state legislatures to adopt any regulatory measure directed at economic affairs which is not clearly arbitrary in the sense of being utterly unrelated to a discernible ill. Moreover, the Court is saying that whether or not the ill should be eradicated is for the legislature to decide. In doing this, the Court is returning a good part of the way towards what appears to have been the original interpretation of these concepts as they relate to the substantive content of economic regulations. ${ }^{62}$ And again the approach accords with the self-conception of himited judicial powers to interfere with legislative determinations.

Turning now to the equal protection clause cases involving Negro rights, let us first start with cases which do not involve segregation-cases where

60 United States v. Darby, 312 U.S. 100, 123-24 (1941).

61 The Court has departed to some degree from this approach in cases involving state regulations which impede interstate commerce. It continues to view the commerce clause as a limitation on what states can do, even in the absence of congressional action, and consequently continues to hold invalid some state regulations which substantially diminish the flow of goods across state lines, Dean Milk Co. v. City of Madison, 340 U.S. 349 (1951), or impose heavy financial burdens on interstate commerce, Southern Pacific Co. v. Arizona ex rel. Sullivan, 325 U.S. 761 (1945) ; Bibb v. Navajo Frejght Lines, Inc., 359 U.S. 520 (1959). The Court has not, however, based its decisions on the "purposes" of such regulations. Rather, it has determined what the effects of such regulations are on interstate commerce and has balanced the detriments of such effects against the benefits flowing to the states from the regulations in order to reach its decisions. But cf. H.P. Hood \& Sons v. Du Mond, 336 U.S. 525 (1949). Perhaps such an approach is unavoidable unless the basic purpose of the commerce clause, to minimize trade barriers between the states, is to be significantly frustrated. See, e.g., Baldwin v. G.A.F. Sechg, Inc., 294 U.S. 511 (1935).

62 Slaughter-House Cases, 83 U.S. (16 Wall.) 36, 80-81 (1873). I do not believe it necessary to treat here the justifications for continuing to view the due process clause of the fourteenth amendment as a limitation on state action which deprives individuals of some of the specific substantive protections included in the Bill of Rights while contemporaneously reading out of the same clause most limitations on state economic regulation. $C f$. United States v. Carolene Prod. Co., 304 U.S. 144, 152-53 n.4 (1938); BLACK, The PeOple and the Court chs. 4 \& 5 (1960). If the distinction is justified, an equal protection case involving Negro rights would seen to raise issues similar to those raised in the due process cases involving Bill of Rights protections. If the distinction is unjustified, the argument which follows in the text applies to show why equal protection cases involving Negro rights ought to be treated differcntly than other due process and equal protection cases. 
disadvantages clearly are visited on Negroes. We begin again with the proposition that the equal protection clause prohibits the imposition of disadvantages on Negroes on the basis of race. Would a court be justified to refuse to investigate the hidden aims or purposes of a statute when a charge is made that the statute denies to Negroes the equal protection of the laws by imposing disadvantages or withholding advantages on the basis of race? If the law classifies on the basis of race and is found to impose disadvantages on Negroes which do not flow merely fron the Negroes' interpretation of the law, the question need not be asked. ${ }^{63}$ Such a law automatically is invalid without inquiry into hidden aims or purposes. But if the law inerely imposes disadvantages on Negroes without so classifying, how can the Court determine whether the proscribed basis is being used? The major indication is found in the classifying factor itself. If it puts Negroes in one class and whites in another and appears to have no demonstrable relation to any purpose but to disadvantage the Negroes, the statute should be invalid. And so it has been held in the "grandfather clause" cases. Implicit in such holdings, however, is the conclusion that the legislature actually classified on the basis of race, though it did not say so in the statute. Obviously the Court considers the statutory classification merely as a sophisticated statement of a racial classification. But is not the Court here doing just what it refuses to do in the economic regulation cases? Is it not deternining what was the "real," as distinguished from the "stated," basis of classification? And must it not do this?

It becomes nuch more difficult for the Court to determine whether a state has imposed disadvantages on the basis of race when the statute uses a nonracial classification and the classification seems to support a generally accepted policy, but in fact casts disadvantages much more heavily on Negroes than on others. Take as examples the literacy requirements for voting and property qualifications for jurors. In both instances it is undoubtedly demonstrable that many more Negroes are excluded on these bases than whites. But can it be said that classifications of literate and illiterate and property owners and non-property owners are substitutes for racial classifications? One suspects that in some cases they are. But it is generally accepted that literacy is a permissible criterion for voting. ${ }^{65}$ And ownership of property has a long historical tradition as a criterion for a jury selection ${ }^{66}$ Because each is reasonably related to the advantage provided, it is virtually impossible to determine whether they are being used for ulterior purposes banned by the equal protection clause and the fifteenth

03 E.g., Smith v. Allwright, 321 U.S. 649 (1944); Ex parte Virginia, 100 U.S. 339 (1879).

64 Lane v. Wilson, 307 U.S. 268 (1939); Guinn v. United States, 238 U.S. 347 (1915).

65 Lassiter v. Northampton County Bd. of Elections, 360 U.S. 45, 51-52 (1959).

66 Brown v. Allen, 344 U.S. 443, 466-74 (1953). 
amendment. The impossibility is compounded by the usual lack of any clear-cut proof that the law makers actually aimed to disadvantage Negroes qua Negro by imposing such criteria. In such situations, the Court has refused to invalidate the law. These refusals seem proper, for the Court can by no means be sure that the legislature has acted wrongly.

But there are other situations which are less ambiguous. Take, for instance, the situation presented in Davis v. Schnell. ${ }^{67}$ In 1946, by popular vote, Alabama adopted the so-called Boswell Amendment to its constitution. The amendment prescribed as one of the qualifications for voting that an applicant be able to "read and write, understand and explain any article of the Constitution of the United States." Under Alabama law the board of registrars in each county made the final determination whether the applicant satisfied these requirements. After the adoption of the amendment a number of Negroes in Mobile, one of Alabama's 67 counties, were refused registration because they had not satisfied the registrars that they could understand and explain various sections of the Constitution. They brought suit for a declaratory judgment that the Boswell Amendment was unconstitutional and for injunctive relief against its further enforcement. The evidence at trial apparently concerned voting practices only in Mobile County. It indicated that after the adoption of the amendment and prior to the filing of the suit, 39 Negroes had been registered; that after the filing of the suit 65 Negroes were registered and 57 rejected all on the grounds of failure to explain provisions of the Constitution. The evidence also indicated that most Negro applicants were asked to explain constitutional provisions, that most whites were not so asked, and that only three whites had been denied registration because of their inability to do so. In addition, it was established that in 1947 and 1948, 2,800 whites and 104 Negroes had been registered in the county which had a total population of 230,000 , of which 64 percent was white and 36 percent Negro.

The federal district court declared the Boswell Amendment unconstitutional and issued the demanded injunction. It first found that the words "understand" and "explain" were inherently ambiguous and offered no discernible standard to guide the registrars in determining the qualifications of applicants. It next reviewed the legislative history of the Boswell Amendnent to determine if the qualifying language was intended to have a definite meaning and concluded that "a careful consideration of the conditions existing at the time, and of the circumstances and history surrounding the origin and adoption of the Boswell Amendment, and its subsequent application, demonstrate that its main object was to restrict voting on a basis of race or color." Finding that "it, thus, clearly appears that this Amend-

6781 F. Supp. 872 (S.D. Ala.), afj'd, 336 U.S. 933 (1949).

6881 F. Supp. at 880 . 
ment was intended to be, and is being used for the purpose of discriminating against the applicants for the franchise on the basis of race or color," ${ }^{19}$ the court held the amendment unconstitutional on its face and not merely as applied in the case. The United States Supreme Court affirmed without opinion. ${ }^{70}$

If the courts find it necessary to go below the surface of legislation which does not patently classify on the basis of race in order to enforce the prohibitions of the fourteenth and fifteenth amendments, is there any less reason to so inquire when dealing with statutes which make patent racial classifications? It would seem not. In fact, it is arguable that there is greater justification in the latter type case where one reasonably can suspect a discriminatory purpose.

It is difficult to state in general terms when a court should rely on the non-explicated purposes of a statute to determine its constitutionality. Clearly, reliance is unjustified when purpose is irrelevant. But when purpose is relevant, as where the determination necessarily turns on whether the state has classified on the basis of race or whether the state designedly imposed the disadvantages on a racial group which in fact flow from the statute, then reliance is justified if purpose is clear. ${ }^{71}$ Clarity, however, is important. The court must be strongly convinced that a chief purpose of the statute is improper before it strikes the statute down, lest the court interfere unduly with legislative decisions. One can find border-line cases where the decision is difficult. State enforced racial segregation, however, is not on the border line; Negroes are harmed by being made to feel inferior because the state has isolated them from whites in order to achieve this very end. Segregation and the maintenance of "white supremacy" are handmates.

\section{$\mathrm{V}$}

Professor Pollak in a 1957 article vigorously defended the result in the Brown case against the usual attacks leveled by Southern critics. ${ }^{72}$ In that article, however, Pollak expressed some dissatisfaction with the way the Chief Justice's opinion determined that segregation "harms" Negroes and

60 Ibid.

70336 U.S. 933 (1949).

71 The approach suggested is similar to that used by the Court in Flemming v. Nestor, 363 U.S. 603 (1960), where one of the questions was whether $\$ 202(n)$ of the Social Security Act, 68 Stat. 1083 (1954), as amended, 42 U.S.C. $\$ 402$ (n) (1958), which provided for the termination of social security benefits under certain circumstances, was an unconstitutional ex post facto law. The determination turned on whether the provision was to be deemed a "punishment" for past conduct not unlawful when engaged in. The Court said that this determination depended on the unexplicated object of the provision which in turn depended on unpostulated legislative intent.

72 Pollak, The Supreme Court Vnder Fire, 6 J. PuB. L. 428 (1957). 
the manner in which it handled the historical question: Did the framers of the equal protection clause intend to prohibit segregation; if not, can a contemporary Court hold segregation barred by the clause?78

In his most recent article, Professor Pollak offers an alternative rationale for the decision. In it he avoids the dilemma of historical analysis by reading the history of the amendinent, as does Professor Alexander Bickel, "as contemplating an essentially dynamic development by Congress and this Court of the liberties outlined in such generalized terms in the Amendment." the questions presented as "(1) whether there is a demonstrable state need for the racial divisions imposed by "Jim Crow" laws here involved, and (2) whether these racial divisions work significant harm to the segregated Negro." ${ }^{.75}$ He then starts his analysis with a quotation from Korematsu v. United States" ${ }^{76}$ that " "all legal restrictions which curtail the civil rights of a single racial group are immediately suspect" " and are "not entitled to the ordinary presumptions of validity," and concludes that segregation laws cannot be sustained unless the states which have them affirmatively prove that such laws are not conceivably unreasonable or harmful to Negroes.

The statement of the question in this form makes it unnecesary for the Court to determine whether in fact segregation legislation is unreasonable or harmful, but Professor Pollak thinks that the Court would be "less than candid" if it failed to state that "denial of the degrading effects of such legislation seems to ... border on the disingenuous" is "unpersuaded that there are demonstrable differences other than those of pigment between whites and Negroes, or that any state policy other than the impermissible one of nourishing race prejudice... underlies the requirement that the races be separated." Pollak is of the view that it would be "corrosive of the judicial function ... to translate [this] amateur wisdom into constitutional imperative."

Fortunately for him, the Court need not pursue "such a ruinous course," for the record does not support a conclusion that the initially stated presumption of invalidity has been overcome, i.e., the states involved have not shown that no reasonable case can be made supporting the conclusion that the racial distinctions are unreasonable and harmful to Negroes. Hence the legislation cannot be sustained.

73 Id. at $437,440-43$.

74 Pollak 25.

75 Pollak 26.

76323 U.S. 214,216 (1944).

77 Pollak 27.

78 Id. 26-27.

79 Id. at 28.

so Ibid. 
By means of this analysis, Professor Pollak cures the two defects which he highpointed in his 1957 article (proof of harm and history), flatly overrules Plessy $v$. Ferguson, and provides a basis for the later per curiam opinions of the Court outlawing segregation in areas other than public education.

\section{VI}

Professor Pollak's ingemious opinion, however, is not without internal difficulties. The heart of its rationale hes in the presumption of invalidity stated in the words from the Korematsu opinion. Once this presumption is created and explained all else falls into place. Segregation laws are presuniptively invalid. The state must affirmatively prove their reasonableness. The states have failed. Ergo, the laws are invalid.

The primary difficulty perceived is, "When does the presumption apply?" Is it, in the words of Korematsu, only when one deals with "legal restrictions which curtail the civil rights of a single racial group?" If so, as Professor Pollak by his quotation froin Korematsu would imply, is not the question in the Brown case: Are the civil rights of Negroes curtailed? If this is the fonnulation, how can one determine whether or not separate but physically equal schools curtail the civil rights of Negroes unless it is shown that Negroes are harned by such segregation? Without such harm or some disadvantage there seems to be no curtailment. (Korematsu was not involved with this inquiry because the civil rights of a single racial group, persons of Japanese origin, were concededly curtailed by the Exclusion Laws.)

Plessy v. Ferguson held that Negroes are not harmed (in a legal sense) by such segregation because segregation laws "neither impose nor imply inequality except as such inequality lies in the eye of the beholder." 81 Professor Pollak rejects this analysis; but he doesn't explain by his rejection how Negroes automatically are conceived as harmed by segregation. It would appear that this still must be shown for the presumption to operate. But Pollak finds it unnecessary to determine whether Negroes are in fact harmed by state-imposed segregation; at best, he says that the states involved have the burden of showing that such could not possibly exist and have failed to satisfy that burden. Thus Professor Pollak has done either one of the following: (1) he has assumed without justification that the Korematsu presumption applies (that civil rights of Negroes are curtailed); (2) he has created a presumption which relies on another, practically irrebutable, presumption (presumption of invalidity based on presumption of harm) without explaining why one should make the second presumption. The second alternative is certainly the better from Professor Pollak's point

81 Id. at 26 . 
of view. But what is it but a statement that state-imposed segregation in education is invalid because Negroes are "irrebutably" presumed to be harmed by such segregation? Why this "irrebutable" presumption? Professor Pollak does not say. Certainly it must come from somewhere; the somewhere must be the Court's knowledge of actual circumstances. It would seem that justifiably to invoke the Pollak presumption the Court must do what Professor Pollak eschews-it must determine, at least initially, whether or not Negroes are harmed by segregation.

My major difficulties with Professor Pollak's position are that (1) he ignores the analysis based on umque facilities, which avoids the whole question of harm, and (2) he does not really cure the prime defect which he perceives in the opinion.

\section{VII}

The alternative construction of the Brown opinion which I have urged accomplishes two major results. First, it lessens the importance of the finding of "harm" in the Chief Justice's opinion. Second, it provides for the later per curiam decisions of the Court in non-school segregation cases a basis which would not have required lengthy explanation to illustrate its applicability. Both of these results I feel are desirable, although not essential.

In substance, the unique facilities approach leads to the eventual conclusion that a state is prohibited from withholding from any individual, solely on the basis of race, access to any of its facilities. Moreover, the state is similarly prohibited from requiring others to withhold such facilities on such basis. The conclusion is justified because any facility can reasonably be treated as unique. No two swimming pools can be exactly the same, if for no other reason than location and setting. No two bus seats can command the same view or the same insulation from exhaust fumes.

The approach limits the finding of "harm" in Brown to an obvious justification for the suggested rule. Although I have no difficulties in agreeing that substantial "harms" are intentionally visited on Negroes by racial segregation, I am reluctant to adopt "harm" as the constitutional pivot in judging segregation statutes. Two reasons support this reluctance. First, I can envisage segregation statutes which arguably would not cause "harm" -at least "harm" of the sort visited on Negroes by segregation. For instance, would whites be "harmed" if Negroes obtained an electoral majority in a southern town and unwisely instituted enforced segregation? Arguably no. Yet I would hope that the Constitution would prohibit such action. Second, it seems to me that a balancing of "harms" is a necessary ingredient to a decision holding that racial segregation is prohibited because it purposely visits "harms" on Negroes. I have little trouble balancing the evident "liarms" in the context of the Brown case. I might have considerably 
more difficulty where "harms" are not as obvious or where the competing "harms" are more closely balanced.

The approach provides a more acceptable basis for the Court's later per curiam decisions in non-school segregation cases. If the Brown decision turned on the purposeful visitation of "harms" on Negro children in the sense that school segregation makes Negro children feel inferior, which in turn detrimentally affects their motivations to learn, then arguably it would have been wise for the Court to have shown how bus, park, golf course, swimming pool, and bathing beach segregation, each causes "harms" to Negroes which are not counterbalanced by other considerations persuasive to some. The unique facilities approach obviates this necessity.

Lastly, if I am wrong in nry construction of the Chief Justice's opinion in the Brown case, I aun content to view it as a stepping stone to the eventual conclusion that the fourteenth amendment prohibits all classifications on the basis of race. Although a general test based on "harm" is susceptible to the criticisms outlined, the Brown case presented a clear instance where a "harm" test could be applied without the dangers perceived by those criticisms. 